\title{
BREVES REFLEXÕES SOBRE O DIREITO À PROVA E À PROVA ILÍCITA NO PROJETO DO NOVO CÓDIGO DE PROCESSO CIVIL
}

\author{
BRIEF REFLECTIONS ON THE RIGHTS TO PROOF AND TO ILLEGAL PROOF \\ IN THE PROJECT OF THE BRAZILIAN NEW CODE OF CIVIL PROCEDURE
}

\author{
Elimar Szaniawski
}

RESUMO: o presente estudo consiste em uma reflexão crítica sobre a supressão, no Relatório Geral do senador Valter Pereira, do parágrafo único do artigo 257 do Projeto de Lei n ${ }^{\circ}$ 166/2010 do Senado, matéria que foi tratada, na Câmara dos Deputados, no artigo 353 do Projeto de Lei n. ${ }^{\circ}$ 8046/2010, a instituir o novo Código de Processo Civil. Partindo da análise do inciso LVI do artigo $5^{\circ}$ da Constituição, sob a ótica da teoria da prova ilícita, da teoria dos frutos da árvore envenenada e do critério da proporcionalidade - teorias sufragadas pelos tribunais superiores e aplicadas no direito brasileiro, este trabalho analisa a relativização do conceito de prova ilícita, dos direitos de personalidade e de outros direitos fundamentais. A noção da categoria da prova ilícita e da teoria dos frutos da árvore envenenada não é absoluta; admite temperos, não sendo, outrossim, incompatível com a aplicação do critério da proporcionalidade no direito brasileiro. O citado parágrafo único do artigo 257 possibilitaria relativizar o rigor da rejeição das provas ilícitas no processo, devolvendo ao juiz a função de ponderar, em cada caso concreto, os princípios, os direitos de personalidade e os direitos fundamentais, porventura colidentes, e o modo pelo qual foi captada a prova dentro das circunstâncias específicas do caso, determinando pela admissibilidade ou não da prova apresentada. A supressão do dispositivo em apreço se traduz em um ato precipitado e irrefletido dos nossos legisladores, permitindo que a parte fique sem a devida tutela diante da violação de um direito moral elevado.

PALAVRAS-CHAVE: Direito à prova. Novo Código de Processo Civil. Princípio da proporcionalidade. Prova ilícita. Teoria dos frutos da árvore envenenada.

ABSTRACT: This study is a critical reflection on the suppression, at the General Report of senator Valter Pereira, of the sole paragraph of the article 257 of the Bill Project $n^{\circ} 166 / 2010$ (Senate). The matter regarding this paragraph was later treated in the article 353 of the Bill Project $n^{\circ}$ 8046/2010 (Chamber of Deputies), which aims to establish the new Brazilian Code of Civil Procedure. Based on the analysis of item LVI, Article 5 of the Constitution, from the perspective of the theories of illegal evidence and of the fruit of the poisonous tree, and from the principle of reasonableness (theories and principle upheld by the superior courts and applied in Brazilian law), this paper analyzes the relativization of the illegal evidence concept, of personal rights and other fundamental rights. The cited theories are not absolute; they can be tempered, not being, moreover, incompatible with the application of the principle of reasonableness, according to Brazilian law. The suppressed paragraph could make it possible to relativize the current rigorous rejection of illegal evidence, restoring to the judge the role of

\footnotetext{
* Bacharel em Direito pela Universidade Federal do Paraná (1974). Mestre em Direito pela Universidade Federal do Paraná (1989). Doutor em Direito pela Universidade Federal do Paraná (1997). Professor Associado e Chefe do Departamento de Direito Civil e Processual Civil da Universidade Federal do Paraná. Conselheiro Consultivo da Revista Jurídica Mater Dei. Membro do Instituto de Direito Comparado Luso-Brasileiro. Membro do Instituto dos Advogados do Paraná.

Revista da Faculdade de Direito - UFPR, Curitiba, vol. 59, n. 2, p. 175-197, 2014.
} 
considering, on a case-by-case basis, the principles, rights of personality and fundamental rights, together with how evidences are raised within the specific circumstances of the case, so determining if the evidence can be admitted or not. The removal of the article in question translates into a hasty and thoughtless act of our lawmakers, which can deprive the parties of adequate protection in the event of violation of a higher moral law.

KEYWORDS: Illegal evidence. New Brazilian Code of Civil Procedure. Principle of reasonableness. Theory of the fruit of the poisonous tree. The right to proof.

\section{INTRODUÇÃO}

Estamos, mais uma vez, às vésperas da promulgação de um novo diploma jurídico brasileiro. Trata-se do Novo Código de Processo Civil, o qual poderá vigorar em breve.

Distante de possuir índole renovadora, a futura lei processual tal qual se apresenta para aprovação distanciou-se das motivações originárias, apresentando-se como um "projeto frankensteiniano", cujo texto não possui um fio condutor coerente, estando eivado de mutilações e interpolações decorrentes de negociações políticas mal feitas e isento de cientificidade. (FERREIRA; ENZWEILER, 2013, p. 1).

O advento da proposição de nova legislação processual civil provoca polêmica entre os juristas que operarão e aplicarão a norma.

O Projeto de Lei do Novo Código de Processo Civil (PNCPC) desperta nossa especial atenção para o tema do direito fundamental à prova judiciária, sua colisão com outros direitos fundamentais e a indagação sobre a possibilidade da utilização de prova ilícita em determinados casos concretos, que se constituirá no objeto do presente estudo.

O dispositivo legal inaugural em matéria probatória é encontrado na Seção 1, do Capítulo XIII, do Título 1, da Parte Especial do atual Código de Processo Civil (CPC), cujo art. 353 traz a cláusula geral que rege a atividade probatória no processo civil brasileiro. Diz o referido artigo:

As partes têm direito de empregar todos os meios legais, bem como os moralmente legítimos, ainda que não especificados neste Código, para provar a verdade dos fatos em que se funda o pedido ou a defesa e influir eficazmente na convicção do juiz. (BRASIL, 1973).

O PNCPC pretende transformar o processo civil brasileiro em um instrumento afinado com o contexto social no qual serão produzidos seus resultados. Todavia, nas questões pertinentes aos meios de captação de provas e sobre o problema da colisão do direito à prova e à tutela da personalidade da pessoa humana, o código pouco avançará. 
O processo civil da atualidade, concebido para tutelar o ser humano individual e seu patrimônio contra os atentados praticados por outro ente individual, não acompanha na mesma velocidade a evolução social, permanecendo, por esta razão, do lado externo da circunscrição da sociedade transmoderna. Assim, os mecanismos jurídicos destinados a tutelar uma sociedade em permanente ebulição se mostram deficientes e lacunosos. Neste quadro, seria necessária uma profunda mudança da concepção ideológica individualista do processo e dos direitos a ele conexos, a exemplo do exercício do direito à prova e da produção da prova judiciária.

Atento a esta complexa problemática, procura o legislador acolher os reclamos da sociedade brasileira e adequar o novo diploma legislativo às necessidades atuais.

O possível Novo Código de Processo Civil, originário do Projeto de Lei n 166/2010 do Senado, procurou inovar, na sua versão original, o tema da prova judiciária, inspirado no direito processual civil alemão, determinando, no parágrafo único do art. 257, sobre a excepcional admissibilidade da prova ilícita no processo civil brasileiro. Reza o citado dispositivo:

\footnotetext{
Art. 257. As partes têm direito de empregar todos os meios legais, bem como os moralmente legítimos, ainda que não especificados neste Código, para provar fatos em que se funda a ação ou a defesa e influir eficazmente na livre conviç̧ão do juiz. Parágrafo único. A inadmissibilidade das provas obtidas por meio ilícito será apreciada pelo juiz à luz da ponderação dos princípios e dos direitos fundamentais envolvidos. (BRASIL, 2010).
}

A inovação consistia em outorgar ao juiz o poder-dever de ponderar os princípios e os direitos fundamentais colidentes, decidindo se determinada prova obtida por meio ilícito poderia ser ou não ser admissível, no caso concreto.

Optou o legislador por admitir, mesmo que excepcionalmente, que pudesse o magistrado deferir à parte o direito de produzir determinada prova, mesmo que fosse uma prova ilícita.

No entanto, a senadora Niura Demarchi apresentou a Emenda $n^{\circ} 30$, por meio da qual propõe a supressão do citado parágrafo único do art. 257, no sentido de que a expressão moralmente legítimas não pode implicar o acolhimento de provas ilegais. Justifica a senadora que o parágrafo induziria à conclusão de que provas ilícitas poderiam ser acolhidas, contrariando, desta forma, a jurisprudência do Supremo Tribunal Federal (STF), que as considera nulas por inconstitucionalidade e devido à adoção da chamada teoria dos frutos da árvore envenenada. 
A proposta de emenda da senadora Niura Demarchi foi acolhida, sendo suprimido o dito parágrafo, sob o fundamento de que, se o citado dispositivo viesse a ser convertido em lei, esta afrontaria a Constituição da República. Ainda, segundo o Parecer do Relator, Senador Valter Pereira, a admissibilidade de provas ilegais vem sendo condenada pelo STF, sob o fundamento de sua inconstitucionalidade, tendo esta corte invalidado decisões cujas provas foram obtidas por meios ilícitos ou a partir de outras provas delas derivadas, o que torna inviável a manutenção do parágrafo único do art. 257.

Desta maneira, o citado dispositivo legal foi retirado no Relatório Geral do senador Valter Pereira, permanecendo apenas o caput do art. 257, cuja redação pouco diverge em relação àquela do art. 332 do $\mathrm{CPC}$ em vigor.

Esta abrupta supressão do parágrafo único desperta algumas reflexões em relação ao tema da prova ilícita, destacando-se o fato de que o dispositivo legal em apreço não propõe, exatamente, o acolhimento da prova ilícita no processo civil brasileiro; visa, isto sim, propor um critério para a verificação se em determinado caso concreto o meio de captação da prova deverá ser considerado ilícito ou não.

Iniciaremos, no próximo capítulo, nossas reflexões a partir da análise do direito à prova como corolário do direito de acesso à justiça, trazendo algumas considerações sobre a teoria das provas ilícitas e breve análise da teoria dos frutos da árvore envenenada, uma vez que a senadora autora da emenda que propôs a supressão do parágrafo único valeu-se dessa teoria em sua justificação.

\section{O DIREITO DE ACESSO À JUSTIÇA - O DIREITO À PROVA}

$\mathrm{O}$ processo atual reconhece o direito à prova como inerente aos litigantes, como consequência do direito fundamental de acesso à justiça, tutelado no inciso XXXV do art. $5^{\circ}$ da Constituição. O direito à prova está intimamente vinculado ao princípio da busca da verdade no processo, previsto no art. 339 do CPC (Art. 364 do PL 8046/2010).

Sob o ponto de vista exclusivamente processual não deveriam existir limites ou restrições à admissibilidade de qualquer meio de prova no processo, uma vez que, mediante apresentação das provas, pretende a parte demonstrar a veracidade dos fatos alegados com o objetivo de ser realizada a justiça.

No entanto, para evitar conflitos e colisão entre direitos de mesmo grau, o que fatalmente ocorreria, o direito processual civil codificado impõe limites à regra determinante de que "ninguém se exime do dever de colaborar com o Poder Judiciário, para o 
descobrimento da verdade" (BRASIL, 1973, art. 339), procurando harmonizar os diversos direitos que gravitam em torno da pessoa e de sua personalidade. Neste sentido, o art. 347 do CPC (Art. 374 do PL 8046/2010) desobriga o litigante, quando interrogado, de depor sobre fatos criminosos ou torpes que lhe forem imputados e aqueles a cujo respeito, por estado ou profissão, deva guardar sigilo. Excetuam-se destas limitações questões de direito de família, que digam respeito às ações de filiação, de separação judicial, divórcio e de anulação de casamento.

O princípio da busca da verdade no processo é também relativizado no tocante ao depoimento de testemunhas, cuja atuação é limitada pela lei processual de 1973 no art. 406 (Art. 434 do PL 8046/2010), o qual exime a testemunha de depor sobre fatos que lhe acarretem grave dano, bem como ao seu cônjuge e aos seus parentes consanguíneos ou afins, em linha reta, ou na linha colateral até o segundo grau, e sobre fatos a cujo respeito, por estado ou profissão, deva guardar sigilo.

As limitações estabelecidas para relativizar a obrigatoriedade dos litigantes e das testemunhas de colaborar com a justiça para o descobrimento da verdade estende-se a terceiros, consoante dispõe o art. 363 do CPC (Art. 390 do PL 8046/2010). Estes, pelas mesmas razões que informam o direito das partes, ficam isentos de apresentar em juízo documentos concernentes a negócios da própria vida da família, desde que sua apresentação possa violar dever de honra ou se a publicidade do documento redundar em desonra à parte ou a terceiros, bem como a parentes consanguíneos ou afins até o terceiro grau, ou lhes representar perigo de ação penal, no caso de a exibição acarretar a divulgação de fatos a cujo respeito, por estado ou profissão, devam guardar segredo, e se subsistirem outros motivos graves que, segundo o prudente arbítrio do juiz, justifiquem a recusa da exibição.

Outros meios de prova, como a prova pericial e a inspeção judicial, subordinam-se às mesmas regras processuais que dispõem sobre a prova judiciária, embora o ordenamento processual não tenha disposições expressas que limitem essas modalidades de prova. A jurisprudência e a doutrina têm sustentado que tais categorias processuais não podem ultrapassar os limites legais de liberdade estabelecidos para os demais meios de prova.

Estas limitações legais, no tocante à prova judiciária e sua produção, têm como principal fundamento a proteção da personalidade do indivíduo. Assim, as limitações, no tocante à busca da verdade no processo, trazidas pela norma processual civil, asseguram às partes, às testemunhas e terceiros, a proteção à vida íntima, privada e familiar do indivíduo e do grupo, a preservação do sigilo de determinados documentos e das comunicações, assegurando, portanto, o direito ao segredo familiar e ao segredo profissional. 
A Constituição de 1988, no inciso LVI do art. $5^{\circ}$, reduziu a possibilidade da prática de abusos por agentes públicos e pelas próprias partes, na busca da verdade em grau absoluto, mediante proibição expressa da utilização de provas obtidas por meios ilícitos. A exegese predominante do citado dispositivo constitucional é no sentido da inadmissibilidade da utilização da prova ilícita no processo civil brasileiro, o que recrudesceu as discussões sobre a admissibilidade ou não de tais meios de prova.

O ponto nuclear da discussão sobre o tema da prova ilícita, no entanto, não se encontra exatamente no fato da admissibilidade, ou não, da prova ilícita em determinado processo, mas sim na caracterização de ser a captação ou a obtenção de determinado meio de prova um meio ilícito, caracterizando, consequentemente, a prova assim obtida, que seria também ilícita. Tanto a jurisprudência como a doutrina ainda não estabeleceram, definitivamente, critérios que visem determinar até que ponto o meio de captação de prova é lícito e a partir de que momento deixa de sê-lo.

Verifica-se que o direito objetivo, tanto o material como o processual, possuem regras destinadas a tutelar, contra atentados praticados pelo poder público e por particulares, a pessoa e sua personalidade.

No entanto, o sistema jurídico da atualidade não tem se mostrado verdadeiramente eficiente nessa tutela. O sistema legal, construído a partir de uma concepção individualista e patrimonialista, mantém presentes muitos resquícios da ideologia predominante dos séculos XIX e XX, destacada na doutrina processual moderna de Chiovenda, Carnelutti e Liebmann.

Em virtude deste fato, passaremos a analisar, nos próximos itens, os critérios para utilização dos meios de prova e a admissibilidade ou não da prova ilícita.

\subsection{A TEORIA DAS PROVAS ILÍCITAS}

No processo tradicional, os direitos conflitantes adentram no tema da prova ilícita. A prova ilícita pode apresentar-se tanto no processo penal quanto no civil e no trabalhista, pois a busca da verdade em qualquer processo poderá violar os direitos fundamentais de personalidade do indivíduo e outros direitos sujeitos a esta verificação.

No âmbito do processo civil e trabalhista, o CPC estabelece, no art. 332, que: "Todos os meios legais, bem como os moralmente legítimos, ainda que não especificados neste Código, são hábeis para provar a verdade dos fatos, em que se funda a ação ou a defesa". (BRASIL, 1973). 
O PL 166/2010 determinava, no caput do art. 257, atual art. 353 do PL 8046/2010, que: "As partes têm direito de empregar todos os meios legais, bem como os moralmente legítimos, ainda que não especificados neste Código, para provar fatos em que se funda a ação ou a defesa e influir eficazmente na livre convicção do juiz.” (BRASIL, 2010, 2011).

As mesmas dificuldades encontradas pelos operadores do direito em relação à exegese do CPC, em interpretar o que se deve entender por meios moralmente legítimos, volta a provocar polêmica em relação ao texto legislativo do PNCPC, fato motivador de algumas digressões.

São considerados meios legais de prova aqueles definidos em lei, ou seja, tipificados na lei processual. O CPC tipifica o depoimento pessoal, a exibição de documentos ou coisa, a prova documental, a confissão, a prova testemunhal, a inspeção judicial e a prova pericial.

Meios legítimos são os que estão de acordo com a lei, embora a doutrina não poupe críticas aos dispositivos, por sua ambiguidade, imprecisão e possibilidade de interpretação subjetiva - não se enquadram, adequadamente, no conceito de moral. Apesar da generalidade conceitual, predomina o entendimento de que os "meios moralmente legítimos" são aqueles que, embora não estejam especificados em lei, são considerados "idôneos" para se provar a verdade dos fatos no processo. (SANTOS, 1976, p. 27)

A lei processual civil brasileira utiliza os meios de prova tidos como juridicamente idôneos, ou seja, os meios legais e os meios moralmente legítimos, embora as expressões legal e legítima sejam sinônimas.

Mais fácil se torna analisar a figura sob seu aspecto negativo, ou seja, o conceito de meio ilegítimo.

Tanto a prova ilícita quanto a prova ilegítima são consideradas ilegais, não sendo, em princípio, admissíveis no processo.

$\mathrm{Na}$ doutrina encontramos autores que estabelecem distinções entre prova ilícita e prova ilegítima, reputando ambas as espécies como provas vedadas, cuja admissibilidade no processo deverá ser refutada.

A doutrina brasileira, de um modo geral, inspirada em Nuvolone (1966), distingue a prova ilegítima da prova ilícita segundo a natureza da vedação da prova. Será ilegítima a prova cuja proibição for de natureza processual. E ilícita, a prova cuja proibição apresente natureza material. Significa que, apesar de haver, em princípio, igual proibição devido a interesses relativos ao processo em si, a vedação se concentra a favor do indivíduo no próprio direito material, independentemente do processo em si. 
Segundo magistério de Nelson Nery Jr. (2003, p. 720), configura-se ilegal a prova na qual "houver violação do ordenamento jurídico como um todo (leis e princípios gerais), quer seja de natureza material ou meramente processual. Ao contrário, será ilícita a prova quando sua proibição for de natureza material, vale dizer, quando for obtida ilicitamente."

Se estas modalidades de prova forem produzidas em determinado processo, o juiz não deverá valorá-las; caso contrário, incidirá a sanção de nulidade da decisão exarada. Isto porque na busca da verdade dos fatos não pode haver ofensa aos direitos de personalidade, que são os mais ofendidos pela obtenção de provas por meios ilícitos, como é o caso da violação da liberdade, da privacidade ou da imagem da pessoa.

A proteção à personalidade humana limita a atividade probatória no processo, devendo ser resguardado o direito à vida, à liberdade, à privacidade, à intimidade, ao segredo, à imagem, à integridade psicofísica e ao patrimônio mínimo.

Poderá, porém, ocorrer que em determinado processo dois direitos de personalidade diversos estejam em conflito, e, sendo possuidores do mesmo grau, um determinado direito fundamental não poderá simplesmente excluir o outro direito que também é fundamental. Surge, então, a indagação: como harmonizar dois direitos fundamentais em colisão - vale dizer, o direito de provar a verdade dos fatos por todos os meios de prova em direito admissíveis e a salvaguarda do direito de personalidade de uma pessoa que possa vir a sofrer atentado em virtude do exercício do direito à prova e sua produção?

Nas décadas de 1970 e 1980, os tribunais brasileiros procuraram construir a tutela da personalidade humana frente às violações decorrentes da atividade probatória sem, no entanto, alcançar satisfatoriamente uma efetiva tutela da personalidade. Seu mérito, porém, foi o de traçar um caminho para a tutela da personalidade, principalmente após a promulgação da Constituição de 1988, que relativiza e harmoniza os direitos de personalidade e outros direitos fundamentais, bem como abandona o caráter fechado e absoluto da norma, ofertando ao magistrado os mecanismos necessários para dirimir conflitos e colisões entre esses direitos fundamentais. A essa relativização dos direitos de personalidade acrescentou-se a vedação de utilização da prova ilícita pelos tribunais, favorecendo, desta maneira, a tutela da personalidade humana. Não devemos, porém, olvidar que o direito à prova, do mesmo modo, classifica-se como um direito fundamental. Logo, a noção de prova ilícita é, também, relativa, e não absoluta, consoante se verá nos próximos capítulos. 


\subsection{A TEORIA DOS FRUTOS DA ÁRVORE ENVENENADA}

Ultimamente, algumas vozes têm se levantado em debates sobre o advento do Novo Código de Processo Civil e o tratamento que o mesmo deveria dar à problemática dos direitos em colisão, especialmente no que concerne aos conflitos entre o direito à prova e a tutela da personalidade do ser humano. Dentre essas vozes, destaca-se aquela que propõe a transposição para o direito processual civil brasileiro da aplicação da teoria dos frutos da árvore envenenada, o que significa que, em determinado caso concreto, ocorrendo a colisão entre esses dois direitos fundamentais, haveria ampla proteção ao direito da personalidade humana.

Segundo essa teoria, o juiz, ao deferir a prova, deverá verificar se os meios de sua obtenção foram licitamente empregados. O magistrado averiguará se o modo da captação ou de constituição da prova não se configura em crime ou violação de algum direito de personalidade contra quem se pretende produzir a prova em juízo. Se o modo ou o meio de prova empregado pela parte ou pelo próprio Estado violar algum direito da parte contrária, deverá o juiz indeferi-la, pois se constituirá em prova ilegal.

Para contornar as deficiências do sistema probatório, os tribunais vêm aplicando essa teoria - the fruit of the poisonous tree - criada na Suprema Corte dos Estados Unidos. Argumenta-se que, assim como os vícios da "planta são transmitidos aos seus frutos", os vícios na obtenção de uma determinada prova sempre contaminarão as demais provas que dela se originarem. (DRESSLER, 2002, p. 10). Portanto, não só as provas obtidas por meios ilícitos devem ser repudiadas pelo juiz, mas, também, aquelas obtidas por derivação, ou seja, decorrentes do meio de prova obtido ilicitamente. (MEDINA, 2011).

Em um determinado caso concreto julgado pela Suprema Corte Americana, um empregador, desconfiando que um dos empregados da empresa estivesse recebendo propina para favorecimento de determinado fornecedor, resolveu pedir a um amigo que interceptasse as comunicações telefônicas daquele, porém sem requerer, previamente, autorização judicial para tal ato. Por intermédio da interceptação realizada, o empresário acabou por descobrir outro delito praticado pelo empregado suspeito, ficando comprovado que o referido empregado não só estava recebendo propina para favorecimento indevido do fornecedor, como também falsificava a contabilidade da empresa, visando obter vantagem ilícita.

Para o direito americano, a interceptação telefônica não autorizada é qualificada como prova ilícita. A prova obtida por meios ilícitos contamina as demais provas que dela advierem; entre elas, a prova que, no exemplo acima, caracterizaria o desfalque, a qual, 
também, torna-se ilícita por derivação. Entende-se por prova ilícita por derivação aquela que, embora obtida de forma lícita, tem sua obtenção condicionada à existência de outra prova, esta obtida ilicitamente. Devido ao pecado original, tal prova, em princípio lícita, contaminase de ilicitude em decorrência da prova que a originou.

A teoria americana do fruit of the poisonous tree, no entanto, não se apresenta como uma categoria absoluta. Há duas previsões de exceção à proibição, vindo a ser admitida a prova ilícita por derivação nos casos de independent source (fonte independente) e de inevitable discovery (descoberta inevitável). A independent source se caracteriza quando a relação entre a prova ilícita e a obtida por derivação for muito tênue. A inevitable discovery, por seu turno, ocorre quando se constata que a prova derivada da prova ilícita seria inevitavelmente descoberta por outro meio legal. (GRINOVER, 1997).

O STF, contudo, tem aplicado a teoria dos frutos da árvore envenenada, no sentido de que a ilicitude da prova se transmite ao que dela derivar, consoante se depreende dos fundamentos do acórdão referente ao RHC n. ${ }^{\circ}$ 90.376/RJ, da lavra do ministro Celso Mello. Nos fundamentos do julgado, afirma o ministro que

A doutrina da ilicitude por derivação (teoria dos 'frutos da árvore envenenada') repudia por constitucionalmente inadmissíveis os meios probatórios, que, não obstante produzidos validamente, em momento ulterior, acham-se afetados, no entanto, pelo vício (gravíssimo) da ilicitude originária que a eles se transmite, contaminando-os, por efeito de repercussão causal. (BRASIL, 2007).

A teoria dos frutos da árvore envenenada recepcionada pelos tribunais superiores do Brasil, a partir da assertiva de que a prova ilícita originária envenena todas as demais provas obtidas a partir dela, tem aplicabilidade no processo civil, no trabalhista e nos procedimentos administrativos, além do processo penal (MEDINA, 2011, p. 332), e estabeleceria, em princípio, a noção de prova ilícita em grau absoluto, algo que destoa do critério da relativização dos direitos fundamentais no sistema jurídico brasileiro. Além de a mencionada teoria permitir, em certo grau, a impunidade do agente criminoso, ao descartar as demais provas do acervo probatório devido à alegada contaminação, haverá um obstáculo ainda maior à justiça quando certa prova, ilícita por derivação, for a única que a parte puder obter como prova do ato atentatório ao direito de personalidade.

Assim, cabe indagar: sendo a prova indigitada como ilícita, e sendo a única possível de se obter acerca do fato, poderia tal prova, apesar da ilicitude, ser captada e produzida em juízo?

De acordo com o que vimos demonstrando neste estudo, sim; será possível, ainda que em caráter excepcional. 
A propósito, a doutrina desenvolvida na Alemanha, a partir da jurisprudência do Tribunal Federal de Justiça (BGH), admite, excepcionalmente, a produção em juízo de prova captada por meios que não são absolutamente lícitos. A doutrina alemã entende que não se pode encobrir um crime, deixando o criminoso impune, sob a alegação de violação a direito de personalidade do agente. Como contraponto, não se justifica a admissão de eficácia processual na utilização da prova ilícita mediante invocação do princípio da busca da verdade em grau absoluto no processo.

A teoria da prova ilícita, sob a ótica de uma categoria de natureza absoluta, apresenta-se insuficiente para dirimir os conflitos oriundos entre o direito à liberdade de provar em juízo e a proteção dos direitos fundamentais. A teoria dos frutos da árvore envenenada, por sua vez, não estabelece o necessário critério destinado a limitar ou fixar até que ponto o meio de captação de prova é lícito e a partir de que momento deixa de sê-lo. Da mesma maneira, não soluciona satisfatoriamente o grave problema dos direitos fundamentais em colisão. Isto porque a teoria dos frutos da árvore envenenada segue a regra de exclusão (exclusionary rule), baseada na $5^{\mathrm{a}}$ Emenda da Constituição Americana, e do princípio do devido processo legal do direito estadunidense, o qual estabelece não ser admissível qualquer prova que venha a atentar contra os direitos constitucionais do réu. (BERG, 2008, p. 29)

Devido a estes complicadores, entendemos ser necessária a aplicação do critério $d a$ proporcionalidade para aferir se o meio de prova empregado poderá ser utilizado na formação do livre convencimento do juiz.

\subsection{O CRITÉRIO DA PROPORCIONALIDADE-IGUALDADE: INSTRUMENTO EFICAZ PARA DIRIMIR A COLISÃO ENTRE O DIREITO À PROVA E OUTROS DIREITOS}

O critério da proporcionalidade, denominado no direito alemão de Verhältnismäßigkeitprinzip, por meio do qual são ponderados direitos e interesses postos em causa, nos quais existe a colisão de direitos de idêntico grau, foi sufragado pela jurisprudência dos tribunais federais superiores da República Federal da Alemanha.

O BGH alemão, atento às deficiências práticas na aplicação da teoria das provas ilícitas, a qual se mostrava insatisfatória em relação ao direito da parte à prova e à ideia da busca da verdade absoluta no processo, passou a rever sua jurisprudência, partindo para a aplicação do critério da ponderação dos direitos e interesses postos em causa, possibilitando ao magistrado a aceitação e a valoração do conteúdo do meio de prova, indiferentemente ao 
modo pelo qual ocorreu sua captação, embora possa vir a ocorrer, em algumas hipóteses, a violação de certos direitos.

Com efeito, a teoria da prova ilícita se mostra insuficiente para tutelar os direitos de personalidade, principalmente no que diz respeito às limitações trazidas à produção da prova judiciária. Do mesmo modo, simplesmente dizer que determinado meio de prova é ilícito pelo fato de que sua captação teria sido viciada (isto é, haveria um vício por derivação) nos parece ser uma afirmação carente de análise cuidadosa.

O critério da proporcionalidade consiste em um critério de valoração dos interesses postos em causa, diante do surgimento de dúvida ao aplicador do direito, para saber "em que medida um interesse em si mesmo legítimo deve ceder perante outro de valor idêntico ou, mesmo, superior." (LARENZ, 1978, p. 577-8). Ou seja, diante de uma situação concreta em que seja necessário o estabelecimento do "limite da satisfação lícita de um interesse à custa de outro interesse, também, digno de tutela." (SZANIAWSKI, 2005, p. 284). Assim, a tutela de um interesse individual terá que ceder ao interesse alheio individual ou ao interesse coletivo.

O critério da proporcionalidade tem por base as disposições legais do estado de necessidade, interferindo na definição de ameaça ilícita. A ameaça ilícita não é antijurídica se, para a obtenção de um fim não proibido, resultar em uma ação em si mesma conforme ao direito, mas que não é o meio adequado para a obtenção desse fim. (LARENZ, 1978).

Sempre que, em determinado caso concreto, verificar-se a colisão de interesses e direitos tuteláveis, deveremos aplicar o critério da proporcionalidade-igualdade, para, ao examinarmos qual dos direitos, de idêntico valor e em colisão, deverá efetivamente preponderar, melhor assegurar a boa realização da justiça. O princípio da igualdade revela-se como substrato sobre o qual se edificam os direitos fundamentais e os de personalidade, uma vez que ele afasta todas as modalidades de privilégios e de preconceitos. A igualdade somada à proporcionalidade constitui-se em um remédio eficaz na satisfação lícita de um interesse próprio frente a um interesse lícito alheio, dirimindo a colisão de direitos e de interesses tuteláveis em determinado caso concreto. (SZANIAWSKI, 2001, p. 70-1).

$\mathrm{Na}$ aplicação integrada dos princípios da proporcionalidade e da igualdade, constituindo o princípio da proporcionalidade-igualdade, acrescido do princípio do menor sacrifício, o magistrado ponderará os interesses e a ilicitude do atentado, e somente excluirá a ilicitude ao admitir a superioridade do interesse do autor do atentado, obtendo, assim, a salvaguarda do equilíbrio entre valores fundamentais em conflito, e evitando-se, ao final, uma desproporção entre o dano causado e a finalidade buscada. 
Consoante pudemos verificar, não se trata da admissibilidade de uma prova ilícita no processo civil, mas de uma ponderação entre os interesses e a verificação da extensão e do valor da ilicitude do atentado, ficando excluída a caracterização de ilicitude apenas ao reconhecer, o magistrado, a superioridade do interesse do autor do atentado sobre o interesse da vítima, preservando o justo equilíbrio entre os valores em conflito.

\subsection{A APLICAÇÃO DO CRITÉRIO DA PROPORCIONALIDADE PELOS TRIBUNAIS ALEMÃES NA SOLUÇÃO DA COLISÃO DE DIREITOS FUNDAMENTAIS}

A interpretação da colisão entre direitos fundamentais da personalidade de uma parte e o direito à prova de outra, mediante aplicação do critério da proporcionalidade, apontará qual dos direitos em colisão apresenta superioridade em determinado caso concreto. $\mathrm{O}$ magistrado, ao ponderar os interesses postos em causa e verificando a preponderância do interesse do autor do atentado em relação ao interesse da parte que sofreu lesão em seu direito, deverá afastar a ideia de ilicitude da prova, ficando autorizada sua produção.

Dois exemplos pontuais, extraídos da jurisprudência alemã, demonstram a relativização dos direitos de personalidade e a necessária ponderação dos direitos e interesses das partes na verificação da licitude ou ilicitude da prova apresentada em juízo pela parte autora do atentado.

O primeiro aresto, da lavra do BGH, proferido em 6 nov. 1980, julgou o caso de determinada senhoria, que pretendia efetuar o despejo de sua locatária - esta, uma estudante universitária que alugava o apartamento contíguo ao da locadora - valendo-se da captação, e utilização como prova, da imagem da inquilina e de outras pessoas. A locadora, para instruir a ação de despejo, passou a fotografar e a filmar a inquilina e as pessoas do sexo masculino que a visitavam, com o objetivo de utilizar as imagens na demanda judicial, visando provar que a locatária utilizava o imóvel para encontros amorosos e para a prática de prostituição.

O processo subiu ao $\mathrm{BGH}$, que decidiu, com fundamento no $§ 823$ do Código Civil alemão (Bürgerliches Gesetzbuch - BGB), pela existência de atentado contra a esfera individual da inquilina fotografada. Decidiu ainda, na ponderação dos interesses e da proporcionalidade entre o meio e o fim, que a autora ultrapassou os limites da razoabilidade, atentando contra o direito de personalidade da fotografada, e qualificou as fotografias como prova ilícita. (REPÚBLICA FEDERAL DA ALEMANHA, 1981).

O segundo aresto, do mesmo tribunal, proferido em 5 jul. 1979, trata do fato de o réu ter, casualmente, fotografado, a uma distância de 15 a 20 metros, uma criança de nove anos de 
idade, que brincava no pátio de uma escola com outras crianças, sendo que o pátio limitava-se com o imóvel de propriedade do réu, e sem que houvesse o consentimento dos pais da criança. A fotografia tinha por objetivo provar, em ação demolitória, as más condições de conservação do edifício da propriedade vizinha. O pai da criança fotografada, que não era parte na ação demolitória, demandou o fotógrafo, para que este lhe entregasse as fotografias e os negativos nos quais aparecia a imagem do filho.

A corte que julgara originariamente a demanda, o Landesgericht ${ }^{1}$ de Schleswig, decidira por repelir a pretensão deduzida pelo autor, entendendo que, embora houvesse a captação da imagem da criança, esta não era o tema principal da fotografia; tampouco havia sido praticado qualquer atentado ao direito de personalidade do retratado.

Em grau recursal, o BGH confirmou a decisão recorrida, julgando no sentido de que o ato de fotografar uma criança que está brincando em um pátio no meio de outras não lesa direito geral de personalidade, servindo, portanto, a fotografia como meio de prova em um processo judicial cuja finalidade, pedido e causa de pedir, consistem na demolição do imóvel em ruínas; totalmente alheios, portanto, ao tema da criança fotografada. Os fundamentos do acórdão, a partir da aplicação da teoria dos círculos concêntricos de Heinrich Hubmann (1953), declaram que, em princípio, uma fotografia tirada de alguém sem o seu consentimento atenta contra o direito geral de personalidade porque a fotografia cria, para o fotógrafo, a possibilidade de disposição sobre a imagem da vítima.

No presente caso, porém, o BGH verificou que o peso do atentado praticado contra o direito geral de personalidade do fotografado é diminuto. A fotografia de brincadeiras infantis, tirada em público, não chega a atentar contra a esfera privada, nem contra a esfera íntima do fotografado, pois o ato de fotografar em público pode vir a atentar, somente, contra a esfera individual da pessoa. Segundo este raciocínio, está o interessado autorizado a realizar fotografias que lhe proporcionam um meio de prova para um futuro processo, sendo essas admissíveis enquanto não vierem a atingir o âmbito do núcleo do direito geral de personalidade do fotografado. Nesta situação, o fotografar e o reter ou guardar uma fotografia, considerando-se a ponderação dos bens e dos interesses, serão admissíveis, pois o pouco interesse na intocabilidade da esfera individual implica no não atentado ao direito de personalidade do autor, pois o interesse do réu, que teme um prejuízo em seu patrimônio, será preponderante em relação ao interesse do autor. Deste modo, decidiu o Tribunal, com fundamento no $\S 823$, alínea I, do BGB, pela inexistência de lesão ao direito de personalidade

\footnotetext{
${ }^{1}$ Landesgerichte ou der Gerichte Länder são os tribunais que são estabelecidos e utilizados por um ou vários dos dezesseis estados da Alemanha. Seu oposto é a Justiça Federal. (N. do E.)

Revista da Faculdade de Direito - UFPR, Curitiba, vol. 59, n. 2, p. 175-197, 2014.
} 
do fotografado, servindo as fotografias como meio de prova em juízo. (REPÚBLICA FEDERAL DA ALEMANHA, 1980).

Consoante pudemos constatar, a jurisprudência dos tribunais alemães não se posiciona no sentido de admitir, indiscriminadamente e em grau absoluto, a utilização da prova ilícita. Os magistrados realizam uma análise profunda nos elementos da causa, procurando a melhor solução diante da colisão entre o direito fundamental à prova e o direito fundamental de personalidade, devendo decidir qual destes direitos em conflito deverá preponderar em determinado caso concreto.

Segundo nosso entender, a aplicação do critério da proporcionalidade para aferir se o meio de prova empregado pode ser utilizado na formação do livre convencimento do juiz mostra-se como a solução mais eficiente e justa.

\section{A ÓtICA DO PROJETO DO NOVO CÓdIGO DE PROCESSO CIVIL BRASILEIRO NO TOCANTE À PROVA ILÍCITA}

Consoante vimos, o primeiro dispositivo legal relativo ao tema probatório no PNCPC foi o art. 257 do Projeto de Lei $n^{\circ}$ 166/2010 do Senado, o qual foi reformado e, posteriormente, encaminhado à Câmara dos Deputados, vindo a ser identificado como Projeto de Lei $n^{\circ} 8046 / 2010$, que se encontra tramitando com vistas à futura promulgação, e que passou a tratar da matéria em tela em seu art. 353, o qual dispõe que "as partes têm direito de empregar todos os meios legais, bem como os moralmente legítimos, ainda que não especificados neste Código, para provar fatos em que se funda a ação ou a defesa e influir eficazmente na livre convicção do juiz.” (BRASIL, 2011).

O dispositivo praticamente reproduz o art. 332, do atual CPC, o qual dispõe que “todos os meios legais, bem como os moralmente legítimos, ainda que não neste Código, são hábeis para provar a verdade dos fatos, em que se funda a ação ou a defesa" (BRASIL, 1973) e, ao dispor que as partes podem empregar todos os meios de prova moralmente legítimos, deixa o dispositivo em aberto para a assimilação de outras modalidades de prova que não estejam especificadas no Código.

O citado dispositivo constitui-se em uma cláusula geral, aberta às interpretações vindouras, a qual permite a adequação da matéria probatória aos novos meios de prova que no futuro hão de surgir como provas legítimas em favor das partes. Contudo, não traz novidades ao sistema probatório brasileiro.A única inovação trazida no PNCPC consistia no parágrafo único, do art. 257, do Projeto de Lei do Senado n 166/2010, o qual foi subtraído no Relatório 
Final do Projeto, sob a fundamentação de que o mencionado dispositivo admitia a prova ilícita no processo civil brasileiro, fato que seria vedado pela Constituição.

Desta maneira, será necessária uma análise do tema da prova ilícita a partir da Constituição Federal.

A Constituição brasileira determina, no inciso LVI do art. $5^{\circ}$ (BRASIL, 1988), a inadmissibilidade das provas obtidas por meios ilícitos. A tradicional exegese da Constituição brasileira sobre o tema da prova ilícita defende a inadmissibilidade da utilização de provas ilícitas no processo judicial. Assim sendo, o juiz deverá indeferir as provas ilícitas produzidas pelas partes, podendo, em princípio, apenas admitir as provas lícitas. O indeferimento da prova não se atém, somente, às provas ilícitas, consoante vimos acima, sendo também vedadas as demais provas derivadas da prova ilícita.

No entanto, a leitura do inciso LVI do art. $5^{\circ}$ não deve ser realizada sob a ótica de um direito absoluto, uma vez que devem ser preservados os direitos de personalidade consubstanciados segundo o princípio da dignidade da pessoa humana.

O fenômeno da repersonalização do direito - isto é, da colocação da pessoa humana como centro do direito civil, e do direito como um todo, compreendendo que ela está acima da dimensão patrimonial, em razão de sua dignidade essencial - foi responsável pela interpretação das normas favoráveis à visão do ser humano como portador de dignidade e, portanto, deverá a personalidade ser protegida da maneira mais ampla possível, prestigiando o direito ao livre desenvolvimento da personalidade de cada pessoa, segundo a ótica da igualdade material.

Predomina, no direito atual, o critério da relatividade dos direitos fundamentais, entre eles o direito fundamental da personalidade e o direito fundamental à prova judiciária. Sendo ambos os direitos conflitantes fundamentais (ou seja, direitos primeiros previstos na Constituição), será preciso estabelecer qual deles deverá ceder ao outro, pois ambos serão igualmente legítimos. Segundo esta leitura, o próprio direito brasileiro admitia a produção da prova ilícita, uma vez que a exegese dos dispositivos constitucionais de longa data vem admitindo temperos.

As cartas constitucionais de $1967^{2}$ e 1969 , no capítulo destinado a resguardar os direitos e garantias individuais, garantiam o sigilo dos meios de comunicação. $\mathrm{O} \S 9^{\circ}$ do art. 153, da Carta de 1969, determinava expressamente que "É inviolável o sigilo da correspondência e das comunicações telegráficas e telefônicas” (BRASIL, 1969). Segundo a

\footnotetext{
2 Art. 150, § 9 : "São invioláveis a correspondência e o sigilo das comunicações telegráficas e telefônicas." (BRASIL, 1967)
} 
exegese predominante, as Cartas Constitucionais de 1967 e 1969 garantiriam o sigilo em grau absoluto dos meios de comunicação no Brasil.

No entanto, em casos extremamente graves, como os de sequestro e de extorsão, entre outros, alguns magistrados, menos apegados à frieza da letra da lei, e invocando o estado de necessidade das vítimas, viram por bem deferir a escuta telefônica e a interceptação das comunicações dos agentes criminosos.

$\mathrm{Na}$ linha de raciocínio tradicional, a prova captada e produzida poderia ser considerada ilícita.

O sigilo dos meios de comunicação em grau absoluto, portanto, impediria o Judiciário de alcançar os sequestradores e os extorsionistas, deixando a vítima à beira da justiça. Ou seja, ficava salvaguardada, sob o manto da justiça, a personalidade do criminoso, enquanto a vítima permanecia impedida de exercer seu direito de acesso à justiça por falta de provas que a lei considerasse lícitas. Em virtude desta situação injusta, foi modificado o entendimento do grau de sigilo das comunicações, dispondo a Constituição em vigor, no inciso XII do art. $5^{\circ}$, que "é inviolável o sigilo da correspondência e das comunicações telegráficas, de dados e das comunicações telefônicas, salvo, no último caso, por ordem judicial, nas hipóteses e na forma que a lei estabelecer para fins de investigação criminal ou instrução processual penal.” (BRASIL, 1988). ${ }^{3}$

Verifica-se que o próprio constituinte de 1988 relativizou a eficácia e o rigor do direito ao segredo das comunicações telefônicas do suspeito, tendo a jurisprudência, acertadamente, ampliado a relativização à investigação de documentos e dados, materiais e eletrônicos. (cf. BRASIL, 1999).

De outro lado, cumpre esclarecer que a Constituição não autoriza a intervenção absoluta nas comunicações de terceiros. O que poderá ocorrer, diante do evidente interesse público, será o deferimento de autorização judicial para a busca e apreensão do material antes da remessa ou após a chegada ao destino, com acesso posterior ao conteúdo das mensagens e à identificação do remetente e do destinatário, com as intervenções nas comunicações sempre respaldadas pelo interesse público.

Não se confunde, pois, a interceptação de documentos ou correspondência com a busca e apreensão de documentos e discos rígidos de computadores de pessoas jurídicas, realizadas quando há indícios da prática de ilicitudes. Neste caso, nas palavras do ministro Sepúlveda Pertence, "não há violação do art. 5, XII, da Constituição [...], pois não houve

\footnotetext{
${ }^{3} \mathrm{O}$ inciso XII, parte final, do art. $5^{\circ}$ da Constituição é regulamentado pela Lei no 9296, de 24/07/1996.
}

Revista da Faculdade de Direito - UFPR, Curitiba, vol. 59, n. 2, p. 175-197, 2014. 
quebra de sigilo das comunicações de dados (interceptação das comunicações), mas sim apreensão de base física na qual se encontravam os dados, mediante prévia e fundamentada decisão judicial”. (BRASIL, 2006).

O STF, por meio de inovadora exegese e com fundamento no interesse público, amplia a possibilidade do acesso das investigações a dados e comunicações devidamente autorizadas por decisão judicial. Com efeito, limitar a interpretação da Constituição no que diz respeito apenas ao acesso das comunicações telefônicas, impedindo o acesso aos demais dados e comunicações, constituir-se-ia em grave afronta ao direito e à personalidade das vítimas, prestando-se as citadas limitações, tão somente, para a salvaguarda dos atentados à pessoa humana e para a prática de atos ilícitos.

A tradicional exegese da Constituição brasileira sobre o tema da prova ilícita, no âmbito do processo civil e trabalhista, que se inclinava no sentido da inadmissibilidade da utilização de provas ilícitas e ilegítimas no processo judicial, está sendo revista mediante nova leitura.

Esta nova postura vem sendo defendida na doutrina pelos autores paranaenses Sérgio Cruz Arenhart e Luiz Guilherme Marinoni, que acolhem a teoria dos frutos da árvore envenenada e admitem sua aplicabilidade no âmbito do processo civil. (cf. ARENHART; MARINONI, 2004, p. 319).

Incorrem em equívoco aqueles que sustentam que a aplicabilidade da teoria dos frutos da árvore envenenada conduzirá, fatalmente, à inadmissibilidade do emprego das provas ilícitas e das provas delas derivadas no processo civil, considerando-se que o próprio direito estadunidense relativiza a citada teoria, por meio das categorias independent source e inevitable discovery, consoante vimos acima.

Vimos, ainda, que a relativização da teoria dos frutos da árvore envenenada permite sua compatibilidade com a utilização do critério da proporcionalidade, não havendo exclusão de uma das teorias pela outra.

A doutrina brasileira vem abrandando o significado absoluto de prova ilícita. A corrente mais liberal tem admitido, excepcionalmente, a utilização da prova ilícita, como recurso último à necessária proteção da personalidade e preservação de um direito moral elevado. Em tais hipóteses, ocorre exceção à vedação legal absoluta.

Objetivando contornar as dificuldades práticas e possibilitar a proteção da personalidade e de um direito moral elevado da parte, o Projeto de Lei do novo CPC determinava, originalmente, no parágrafo único do art. 257, que: “A inadmissibilidade das 
provas obtidas por meio ilícito será apreciada pelo juiz à luz da ponderação dos princípios e dos direitos fundamentais envolvidos." (BRASIL, 2010).

O dispositivo legal proposto relativiza o rigor da rejeição da utilização das provas ilícitas no processo, devolvendo ao juiz a função de ponderar, em cada caso concreto, os princípios, os direitos de personalidade e fundamentais colidentes e o modo pelo qual foi captada a prova dentro das circunstâncias específicas do caso, determinando, ao final, pela admissibilidade ou não da prova apresentada.

O critério da ponderação para a utilização excepcional da prova ilícita, no processo civil, deverá ser aplicado onde haja risco de se ver desprotegido um direito moral elevado de uma das partes. E terá por função prestigiar a atividade probatória do litigante e de garantir o seu resguardo.

A supressão do parágrafo único do art. 257, no relatório final do Projeto de Lei 166/2010, que encontra correspondência no atual art. 353, do Projeto $n^{\circ}$ 8046/2010, apresenta-se para nós como um lamentável retrocesso na atividade probatória das partes. Tal omissão legislativa, se e quando o Projeto vier a se tornar lei, servirá como uma válvula de escape para os que praticam atos ilícitos, proporcionando-lhes impunidade, ante a impossibilidade de a parte lesada produzir legalmente sua prova; vale dizer, ficará a parte lesada sem alcançar justiça.

Nesse sentido, tal supressão constitui-se em um equívoco, fruto do desconhecimento do critério da proporcionalidade e do que seja a teoria dos frutos da árvore envenenada em toda sua extensão, traduzindo-se em um ato precipitado e irrefletido de nossos legisladores.

\section{CONCLUSÃO}

O tradicional sistema processual brasileiro se caracteriza por sua construção individualista, não estando disposto a dirimir conflitos que envolvam a tutela da personalidade segundo a concepção do homem social.

$\mathrm{O}$ advento de um novo CPC, cujo esboço de lei dispõe que as partes podem empregar todos os meios de prova moralmente legítimos, mesmo as que não estejam especificadas no Código (art. 353 do Projeto $n^{\circ}$ 8046/2010), traz uma cláusula geral, com a necessária abertura, destinada a permitir ao operador do direito, diante de novas modalidades de prova que poderão surgir, admiti-las como provas lícitas destinadas à comprovação de determinado fato.

No entanto, a supressão do parágrafo único do art. 257 do Projeto de Lei no 166/2010 do Senado, no seu Relatório Final, e que, atualmente, constitui o art. 353 do Projeto de Lei no 
8046/2010, apresenta-se, para nós, como um retrocesso na atividade probatória das partes. Isso porque esta omissão legislativa permite aos intérpretes mais conservadores realizar uma exegese de natureza absoluta a partir da Constituição, transformando o dispositivo em uma porta de ingresso para a impunidade dos que praticam atos ilícitos, atando as mãos da justiça e impedindo a parte lesada de produzir sua prova e, ao final, receber sua devida tutela judicial.

Com essa omissão no futuro CPC, devido à inoportuna supressão de um dispositivo legal que outorgaria ao magistrado a possibilidade de ponderação dos direitos e interesses das partes postas em causa, eliminando circunstancialmente o caráter ilícito da prova carreada aos autos, o julgador terá de valer-se de critérios extraprocessuais que lhe outorguem um mínimo de meios para estabelecer qual dos direitos fundamentais em conflito deve prevalecer na espécie concreta e, assim, afastar a ilicitude da prova, por meio de ponderação, salvaguardando a benfazeja justiça e prestigiando a tutela de um direito moral elevado da parte.

\section{REFERÊNCIAS}

ARENHART, Sérgio Cruz; MARINONI, Luiz Guilherme. Manual do processo de conhecimento. $3^{\mathrm{a}}$ ed. São Paulo: RT, 2004.

BADARÓ, Gustavo Henrique. Direito Processual Penal. Tomo I. Rio de Janeiro: Elsevier, 2008.

BERG, B. L. Criminal investigation. New York: McGraw-Hill, 2008.

BRASIL. Congresso Nacional. Câmara dos Deputados. Projeto de Lei 8046/2010. Código de Processo Civil. Revoga a Lei no 5.869, de 1973. Apresentado em 22 dez. 2010. Diário da Câmara dos Deputados. Brasília - DF, 4 fev. 2011. Disponível em: <http://www.camara.gov.br/proposicoesWeb/prop_mostrarintegra;jsessionid=21BE74E19B5 2536D35EDA9C5AC633C7F.proposicoesWeb2?codteor $=831805 \&$ filename $=P L+8046 / 2010$ $>$ Acesso em: 4 abr. 2012.

Congresso Nacional. Senado Federal. PLS - Projeto de Lei do Senado, N ${ }^{0} 166$ de 2010. Dispõe sobre a reforma do Código de Processo Civil. Apresentado em 8 jun. 2010. Diário do Senado Federal. Brasília - DF, 9 jun. 2010. Disponível em: $<$ http://www.senado.gov.br/atividade/materia/getPDF.asp?t=79547\&tp=1> Acesso em: 4 abr. 2012.

Constituição da República Federativa do Brasil de 1967. Diário Oficial da República Federativa do Brasil, Brasília - DF, 24 jan. 1967. Disponível em: <http://www.planalto.gov.br/ccivil_03/constituicao/constituicao67.htm>. Acesso em: 14 maio 2013. 
Constituição da República Federativa do Brasil de 1988. Diário Oficial da República

Federativa do Brasil, Brasília - DF, 5 out. 1988. Disponível em: <http://www.planalto.gov.br/ccivil_03/constituicao/Constituicao.htm>. Acesso em: 14 maio 2013.

Emenda constitucional $\mathrm{n}^{\mathrm{o}} 1$, de 17 de outubro de 1969. Edita o novo texto da Constituição Federal de 24 de janeiro de 1967. Diário Oficial da República Federativa do Brasil, Brasília - DF, 20 out. 1969. Disponível em: <http://www.planalto.gov.br/ccivil_03/constituicao/Emendas/Emc_anterior1988/emc0169.htm>. Acesso em: 14 maio 2013.

. Lei 5869, de 11 de janeiro de 1973. Institui o Código de Processo Civil. Diário Oficial da União. Brasília - DF, 17 jan. 1973. Disponível em: <http://www.planalto.gov.br/ccivil_03/leis/L5869compilada.htm>. Acesso em: 14 maio 2013.

Lei 9296, de 24 de julho de 1996. Regulamenta o inciso XII, parte final, do art. $5^{\circ}$ da Constituição Federal. Diário Oficial da União. Brasília - DF, 25 jul. 1996. Disponível em: <http://www.planalto.gov.br/ccivil_03/leis/19296.htm>. Acesso em: 14 maio 2013.

Supremo Tribunal Federal. Segunda Turma. RE $n^{\circ} 219780$ - Pernambuco. Relator: Ministro Carlos Velloso. Partes: Credicard S/A Administradora de Cartões de Crédito vs. Nair Esperança Alves Assis e outros. Julgamento em 13 abr. 1999, publicação no Diário de Justiça em 10 set. 1999. Disponível em: <http://stf.jusbrasil.com.br/jurisprudencia/739492/recursoextraordinario-re-219780-pe>. Acesso em: 14 mai. 2013.

. Supremo Tribunal Federal. Segunda Turma. $R H C n^{\circ} 90376$ - Rio de Janeiro. Relator: Ministro Celso de Mello. Partes: Sérgio Augusto Coimbra Vial vs. Ministério Público Federal. Julgamento em 3 abr. 2007, publicação no Diário de Justiça em 18 maio 2007. Disponível em: <http://www.stf.jus.br/portal/jurisprudencia/listarJurisprudencia.asp?s1=RE\%2890376\%20.N UME.\%29\&base=baseAcordaos $>$. Acesso em: 14 mai. 2013.

. Supremo Tribunal Federal. Tribunal Pleno. RE $n^{\circ} 418416$ - Santa Catarina. Relator: Ministro Sepúlveda Pertence. Partes: Antonio Nabor Areias Bulhões e outro (A/S) vs. Ministério Público Federal. Julgamento em 10 maio 2006, publicação no Diário de Justiça em 19 dez. 2006. Disponível em: <http://stf.jusbrasil.com.br/jurisprudencia/760712/recursoextraordinario-re-418416-sc >. Acesso em: 14 mai. 2013.

DRESSLER, Joshua. Understanding criminal procedure. 3rd ed. Newark, NJ: Lexis Nexis, 2002. ISBN 0820554057.

FERREIRA, Cláudia Galiberne; ENZWEILER, Romano José. O "novo" CPC e a oportunidade desperdiçada. Revista da Esmesc, v. 20, n. 26, 2013. Disponível em: <www.revista.esmesc.org.br/re/article/download/71/78>. Acesso em: 9 jun. 2013.

GRINOVER, Ada Pellegrini. O regime brasileiro das interceptações telefônicas. Revista CEJ, vol. 1, $\mathrm{n}^{\mathrm{o}} 3$, set. / dez. 1997. Disponível em: <http://www2.cjf.jus.br/ojs2/index.php/revcej/article/view/108/151>. Acesso em: 12 abr. 2011. 
HUBMANN, Heinrich. Das persönlichkeitsrecht. Münster: Böhlau-Verlag, 1953.

LARENZ, Karl. Metodologia da ciência do direito. Lisboa: Fundação Calouste Gulbenkian, 1978.

MEDINA, José Miguel Garcia. CPC-Código de processo civil comentado. São Paulo: RT, 2011.

NERY Jr., Nelson; NERY, Rosa Maria de Andrade. Código de Processo Civil comentado e legislação extravagante. $7^{\mathrm{a}}$ ed., São Paulo: RT, 2003.

NUVOLONE, Pietro. Le prove vietate nel processo penale nei paesi di diritto latino. Rivista di Diritto Processuale. Padova: CEDAM, 1966.

REPÚBLICA FEDERAL DA ALEMANHA. Bundesgerichtshof (BGH) (tribunal supremo da República Federal da Alemanha em matéria de competência genérica, ou seja, justiça civil e criminal). Número do processo: 16 L 146/80. Data do julgamento: 6 nov. 1980. Ementa: Einer Wohnungsinhaberin steht ein Unterlassungsanspruch gegen Mitbewohner zu, die sie und ihre Besucher fotografieren, um die Fotos in einem Rechtsstreit als Beweismittel für die Behauptung vorzulegen, die Inhaberin gehe in ihrer Wohnung der Prostitution nach [O morador do imóvel tem direito a uma medida cautelar contra companheiro de quarto que o fotografa, e a seus visitantes, para apresentar as fotos em processo, a servirem como evidência para a afirmação de que o morador utiliza o apartamento para prostituição (Tradução livre)]. $M D R, 1981$, p. 316-7.

Bundesgerichtshof (BGH) (tribunal supremo da República Federal da Alemanha em matéria de competência genérica, ou seja, justiça civil e criminal). Número do processo: $12 \mathrm{~L}$ 1277/79. Data do julgamento: 5 jul. 1979. Ementa: Die Lichtbildaufnahme eines spielenden Kindes stellt auch dann keinen Eingriff in dessen Persönlichkeitsrecht dar, wenn sie als Beweismittel für zivilrechtliche Ansprüche erfolgt. [A fotografia de uma criança brincando não constitui uma interferência em sua personalidade jurídica, se for realizado como prova em processos cíveis. (Tradução livre)]. MDR, 1980, p. 311.

. Bürgerliches Gesetzbuch (BGB) (Código Civil da Alemanha). Em desenvolvimento desde 1881, tornado efetivo em 1 jan. 1900. Disponível em: <http://www.gesetze-iminternet.de/bgb/index.html>. Acesso em: 4 abr. 2012.

SANTOS, Moacyr Amaral. Comentários ao Código de Processo Civil. IV volume. Rio de Janeiro: Forense, 1976.

SZANIAWSKI, Elimar. Apontamentos sobre o princípio da proporcionalidade-igualdade. $R T D C$. Rio de Janeiro. Vol. $\mathrm{n}^{\circ}$ 5. 2.001.

Direitos de personalidade e sua tutela. 2. ${ }^{\text {a }}$ ed. São Paulo: RT, 2005. 


\title{
BRIEF REFLECTIONS ON THE RIGHTS TO PROOF AND TO ILLEGAL PROOF IN THE PROJECT OF THE BRAZILIAN NEW CODE OF CIVIL PROCEDURE
}

\begin{abstract}
This study is a critical reflection on the suppression, at the General Report of senator Valter Pereira, of the sole paragraph of the article 257 of the Bill Project $n^{\circ}$ 166/2010 (Senate). The matter regarding this paragraph was later treated in the article 353 of the Bill Project $n^{\circ}$ 8046/2010 (Chamber of Deputies), which aims to establish the new Brazilian Code of Civil Procedure. Based on the analysis of item LVI, Article 5 of the Constitution, from the perspective of the theories of illegal evidence and of the fruit of the poisonous tree, and from the principle of reasonableness (theories and principle upheld by the superior courts and applied in Brazilian law), this paper analyzes the relativization of the illegal evidence concept, of personal rights and other fundamental rights. The cited theories are not absolute; they can be tempered, not being, moreover, incompatible with the application of the principle of reasonableness, according to Brazilian law. The suppressed paragraph could make it possible to relativize the current rigorous rejection of illegal evidence, restoring to the judge the role of considering, on a case-by-case basis, the principles, rights of personality and fundamental rights, together with how evidences are raised within the specific circumstances of the case, so determining if the evidence can be admitted or not. The removal of the article in question translates into a hasty and thoughtless act of our lawmakers, which can deprive the parties of adequate protection in the event of violation of a higher moral law.
\end{abstract}

KEYWORDS: Illegal evidence. New Brazilian Code of Civil Procedure. Principle of reasonableness. Theory of the fruit of the poisonous tree. The right to proof.

Recebido: 16 de julho de 2014

Aprovado: 15 de agosto de 2014 